\title{
FAKTOR-FAKTOR YANG MEMPENGARUHI RETURN SAHAM
}

\author{
Sri Hermuningsih \\ Anisya Dewi Rahmawati \\ Mujino \\ Universitas Sarjanawiyata Tamansiswa Yogyakarta \\ hermun feust@yahoo.co.id \\ anisyadewi16@gmail.com \\ mujinoust@gmail.com
}

\begin{abstract}
The purpose of this study is to analyze the factors that affect stock returns on manufacturing companies listed on the Indonesia Stock Exchange. The population in this study are Manufacturing companies listed on the Indonesia Stock Exchange in the period 2011-2015 a total of 17 companies sample automotive manufacturing companies sub-sector consisting of 7 companies. This sampling technique uses Purposive sampling. The result of research indicate that: (1) Economic Value Added and systematic risk influence partially influence to stock interest rate return and inflation do not show significant influence. (2) Economic Value Added, systematic risk, interest rate and inflation simultaneously have a significant effect on stock return level (3) EVA is the most dominant variable affecting stock returns on manufacturing companies categorized in the automotive sub-company.
\end{abstract}

Keywords: Economic Value Added, Beta Saham, Inflasi, suku bunga, return saham

\section{PENDAHULUAN}

Perkembangan pasar modal di Indonesia telah memperlihatkan kemajuan seiring dengan perkembangan ekonomi Indonesia. Melalui pasar modal, investor dapat melakukan investasi di beberapa perusahaan melalui pembelian surat-surat berharga yang ditawarkan atau diperdagangkan di pasar modal (Hermuningsih, 2012). Return merupakan tingkat kembalian investasi yang merupakan penjumlahan dari dividend yield dan capital gain. Economic Value Added adalah indikator internal yang mengukur kekayaan pemegang saham suatu perusahaan dalam jangka waktu tertentu. Selain Economic Value Added (EVA) yang digunakan juga risiko sistematis dan indikator makro ekonomi Perubahanperubahan ini tentunya merupakan risiko bagi investor. Risiko ini terbagi menjadi risiko sistematis dan risiko tidak sistematis. Harga saham tidak hanya dipengaruhi oleh kinerja keuangan perusahaan tetapi juga dipengaruhi faktor ekonomi seperti tingkat suku bunga dan inflasi. Jika suku bunga acuan dari bank Indonesia dinaikan, maka suku bunga kredit yang dikeluarkan oleh bank umum juga akan ikut naik.

Berdasarkan latar belakang masalah, maka permasalahan dalam penelitian ini adalah faktor-faktor apakah yang mempengaruhi return saham pada perusahaan manufaktur yang terdaftar di Bursa Efek Indonesia

\section{KAJIAN PUSTAKA \\ Pengertian Saham}

Saham adalah surat berharga yang menunjukkan kepemilikan perusahaan sehingga pemegang saham memiliki hak 
klaim atas dividen atau distribusi lain yang dilakukan perusahaan kepada pemegang saham lainnya. Saham merupakan secarik kertas yang menunjukkan hak pemodal (yaitu pihak yang memiliki kertas tersebut) untuk memperoleh bagian dari prospek atau kekayaan organisasi yang menerbitkan sekuritas tersebut dan berbagai kondisi yang memungkinkan pemodal tersebut menjalankan haknya (Husnan 2005). Saham merupakan salah satu dari beberapa alternatif yang dapat dipilih untuk berinvestasi. Investasi dengan membeli saham suatu perusahaan, berarti investor telah menginvestasikan dana dengan harapan akan mendapatkan keuntungan dari hasil penjualan kembali saham tersebut. Wujud saham adalah selembar kertas yang menerangkan bahwa pemilik kertas tersebut adalah pemilik perusahaan yang menerbitkan surat berharga tersebut dan porsi kepemilikan ditentukan oleh seberapa besar penyertaan yang ditanamkan dalam perusahaan tersebut (Darmadji, 2001).

\section{Pengertian Return Saham}

Return adalah hasil (keuntungan atau kerugian) yang diperoleh dari suatu investasi saham. Return saham bisa positip dan bisa juga negatif. Jika positif berarti mendapatkan keuntungan atau mendapatkan capital gain, sedangkan negatif berarti menderita kerugian atau capital loss

Return merupakan salah satu faktor yang memotivasi investor untuk berinvestasi dan juga merupakan imbalan atas keberanian investor dalam menanggung risiko atas investasi yang dilakukan Tandelilin (2001). Sedangkan menurut Jogiyanto (2003), “ return merupakan hasil yang diperoleh dari investasi. Return dapat berupa return realisasi yang sudah terjadi atau return ekspektasian yang belum terjadi tetapi yang diharapkan akan terjadi dimasa mendatang".

Return realisasi (realized return) merupakan return yang telah terjadi. Return realisasi dihitung berdasarkan data historis. Return realisasi penting karena digunakan sebagai salah satu pengukur kinerja dari perusahaan. Return histori ini juga berguna sebagai dasar penentuan return ekspektasi (expected return) dan risiko di masa datang.

Return ekspektasi (expected return) adalah return yang diharapkan akan diperoleh oleh investor di masa mendatang. Berbeda dengan return realisasi yang sifatnya sudah terjadi, return ekspektasi belum terjadi. Return total merupakan return keseluruhan dari suatu investasi dalam suatu periode yang tertentu

\section{Pengertian Economic Value Added (EVA) \\ Economic Value Added (EVA)} merupakan pengukuran kinerja yang memperhitungkan tingkat biaya modal, yaitu dengan perhitungan laba bersih setelah pajak dikurangi dengan biaya modal. EVA positif menunjukkan perusahaan berhasil memenuhi biaya modal dengan laba bersih setelah pajak, sehingga para pemegang saham akan menerima return dari perusahaan tersebut. Semakin tinggi EVA, maka semakin tinggi return yang diperoleh pemegang saham. Tujuan Economic Value Added (EVA) Economic Value Added (EVA) memberikan pengukuran yang lebih baik atas nilai tambah yang diberikan perusahaan kepada pemegang saham, oleh karena itu menejer yang menitik beratkan pada EVA dapat diberikan telah beroperasi pada caracara yang konsisten untuk memaksimalkan kemakmuran pemegang saham.

\section{Risiko Sistematis (Beta Saham)}

Menurut Jogiyanto (2003), beta merupakan suatu pengukur volatilitas (volatility) return suatu sekuritas atau return portofolio terhadap return pasar. Beta sekuritas ke-i mengukur volatilitas return sekuritas ke-i dengan return pasar. Beta portofolio mengukur volatilitas return portofolio dengan return pasar. Dengan demikian, beta merupakan pengukur risiko sistematis (systematic risk) dari suatu sekuritas atau portofolio relatif terhadap risiko pasar, 


\section{Tingkat Suku Bunga}

Tingkat suku bunga adalah harga dari pinjaman (Sunariyah 2003). Menurut Bank Indonesia (BI) melalui situs resmi www.bi.go. id, suku bunga $\mathrm{BI}$ atau $\mathrm{BI}$ rate adalah suku bunga kebijakan yang mencerminkan sikap atau kebijakan moneter yang ditetapkan oleh bank Indonesia dan diumumkan kepada public. Adapun fungsi $\mathrm{BI}$ rate, yaitu $\mathrm{BI}$ rate diumumkan oleh Dewan Gubernur Bank Indonesia setiap Rapat Dewan Gubenur (RDG) bulanan dan diimplementasikan pada operasi moneter yang dilakukan Bank Indonesia melalui pengelolaan likuiditas (liquidity management) di pasar uang untuk mencapai sasaran operasional kebijakan moneter. Sasaran operasional kebijakan moneter dicerminkan pada perkembangan suku bunga Pasar Uang Antar Bank Overnight (PUAB O/N). Pergerakan di suku bunga PUAB ini diharapkan akan diikuti oleh perkembangan di suku bunga deposito dan pada gilirannya suku bunga kredit perbankan. Dengan mempertimbangkan pula faktor-faktor lain dalam perekonomian, Bank Indonesia akan menurunkan suku bunga apabila inflasi ke depan diperkirakan berada di bawah sasaran yang telah ditetapkan. Besar perubahan suku bunga $\mathrm{BI}$ direspon dengan kebijakan moneter yang di nyatakan dalam perubahan tingkat suku bunga BI. Dalam kondisi untuk menunjukan intensi Bank Indonesia yang telah besar terhadap pencapaian sasaran inflasi, maka perubahan tingkat suku bunga dapat dilakukan dalam lipatan. Pada perusahaan banyak memiliki kondisi struktur modal perusahaan dimana hutang lebih besar daripada ekuitas perusahaan, maka perusahaan akan menanggung biaya bunga hutang yang besar. Hutang atau pinjaman diperoleh perusahaan - perusahaan sebagian dari bank. Jika suku bunga acuhan dari bank dinaikan, maka suku bunga kredit yang dikeluarkan oleh bank umum akan ikut naik. Peningkatan tersebut akan berpengaruh pada biaya bunga pinjaman yang ditanggung oleh perusahaan.

\section{Inflasi}

Inflasi adalah suatu kenaikan harga yang terus menerus dari barang dan jasa secara umum (Iswardono 1999). Menurut Bank Indonesia melalui situs resminya www.bi.go. id, inflasi adalah meningkatnya harga-harga secara umum dan terus menerus. Kenaikan harga dari satu atau dua barang saja tidak dapat disebut inflasi kecuali bila kenaikan itu meluas (atau mengakibatkan kenaikan harga) pada barang lainnya. Pada umumnya penyebab inflasi adalah berkurang neraca perdagangan suatu Negara tukar nilai impor lebih besar dibandingkan ekspornya sehingga menimbulkan defisit. Inflasi timbul karena adanya tekanan dari sisi supplay, dari sisi permintaan, dan dari ekspektasi inflasi. Faktor- faktor terjadinya cost push inflation dapat disebabkan oleh depresiasi nilai tukar, dampak inflasi luar negeri terutama negaranegara partner dagang, peningkatan hargaharga komoditi yang diatur pemerintah dan terjadi negatif supply shocks akibat bencana alam dan terganggunya distribusi. Faktor penyebab terjadinya demand pull inflation adalah tingginya permintaan barang dan jasa relatif terhadap ketersediaannya. Dalam konteks makro ekonomi, kondisi ini digambarkan oleh output rill yang melebihi output potensialnya atau permintaan total (aggregate demand) lebih besar dari pada kapasitas perekonomian. Sementara itu, faktor ekspektasi inflasi dipengaruhi oleh perilaku masyarakat dan pelaku ekonomi dalam menggunakan ekspektasi angka inflasi dalam keputusan kegiatan ekonominya.

Kestabilan inflasi merupakan prasyarat bagi pertumbuhan ekonomi yang berkesinambungan yang pada akhirnya memberikan manfaat bagi peningkatan kesejahteraan masyarakat. Pentingnya pengendalian inflasi didasarkan pada pertimbangan bahwa inflasi yang tinggi dan tidak stabil memberikan dampak negatif kepada kondisi sosial ekonomi masyarakat. 


\section{Pengembangan Hipotesis}

Pengaruh Economic value added (EVA) terhadap Return saham adalah suatu indikator tenteng adanya penambahan nialai dari suatu investasi. Ansori. (2015) menyatakan bahwa Economic Value Added berpengaruh terhadap Return Saham. Perusahaan yang memiliki EVA tinggi (positif) cenderung dapat lebih menarik investor untuk berinvestasi di perusahaan tersebut, karena semakin tinggi nilai EVA maka semakin tinggi pula nilai perusahaan. Apabila laba perusahaan tinggi maka Return yang diberikan kepada investor juga tinggi.

H1: Economic Value Added (EVA) berpengaruh Positif terhadap return saham.

Pengaruh Risiko sistematis terhadap return saham (Beta) merupakan suatu pengukur volatilitas return sekuritas terhadap return pasar. Bila Beta bernilai 1 menunjukkan bahwa return pasar bergerak naik, return sekuritas atau portofolio juga bergerak naik sama besarnya mengikuti return pasar. Beta bernilai 1 menunjukkan bahwa perubahan return pasar sebesar $x \%$ (Jogianto,2003). Bila beta naik maka investor mengharapkan return yang semakin tinggi untuk menutupi tambahan risiko yang ditanggung/sebaliknya. Berdasarkan hal tersebut maka hipotesis yang diajukan adalah

$\mathrm{H} 2$ : Risiko Sistematis berpengaruh positif dan signifikan terhadap return saham.

Pengaruh Tingkat suku bunga terhadap return saham mempengaruhi laba perusahaan dalam dua cara yaitu karena bunga merupakan biaya, maka makin tinggi tingkat suku bunga maka semakin rendah laba perusahaan apabila ceteris paribus, suku bunga mempengaruhi tingkat aktivitas ekonomi dan karena itu mempengaruhi laba perusahaan. Kenaikan suku bunga akan membuat para pemegang saham enggan untuk memegang surat berharga atau saham yang dapat menurutkan tingkat pengembalian (return) mereka. Dalam menghadapi kenaikan tingkat suku bunga para pemegang saham akan menahan sahamnya sampai tingkat suku bunga kembali normal. Apabila tingkat bunga lebih rendah dari return yang diharapkan maka investor memilih menginvestasikan dananya pada saham, sehingga permintaan saham meningkat yang mengakibatkan naiknya harga saham, yang pada akhirnya akan naik pula return saham yang akan diterima oleh investor. Dari uraian tersebut hipotesis dalam penelitian ini sebagai berikut

H3 : tingkat suku bunga berpengaruh negatif terhadap return saham.

Pengaruh Inflasi terhadap return saham bisa mengurangi tingkat pendapatan rill yang diperoleh investor dari investasi yang dilakukannya. Jika tingkat inflasi rendah, maka hal itu menjadi positif bagi investor yang ingin berinvestasi. Jadi inflasi yang tinggi menyebabkan turunnya keuntungan perusahaan, sehingga menyebabkan rendahnya return saham. Inflasi akan menyebabkan kenaikan harga, maka biaya produksi yang harus dikeluarkan oleh perusahaan akan meningkat secara relatif. Peningkatan biaya produksi mengakibatkan harga pokok produksi meningkat. Sehingga akan mengurangi tingkat keuntungan yang dimiliki oleh perusahaan tersebut. Keuntungan yang menurun mengakibatkan penurunan jumlah dividen (cash flow). Menurunnya dividen akan menyebabkan investor akan melepaskan saham tersebut karena memiliki expected return yang buruk, sehingga dapat dikatakan bahwa inflasi berpengaruh negatif terhadap return. Tingkat inflasi yang besar menunjukkan bahwa resiko investasi disemua sektor usaha besar pula, sebab inflasi yang tinggi akan mengurangi tingkat pengembalian dari investor. Dari uraian tersebut hipotesis dalam penelitian ini sebagai berikut :

$\mathrm{H} 4$ : Inflasi berpengaruh negatif terhadap return saham

H5: Economi Value Added, Risiko 


\section{Model Penelitian}

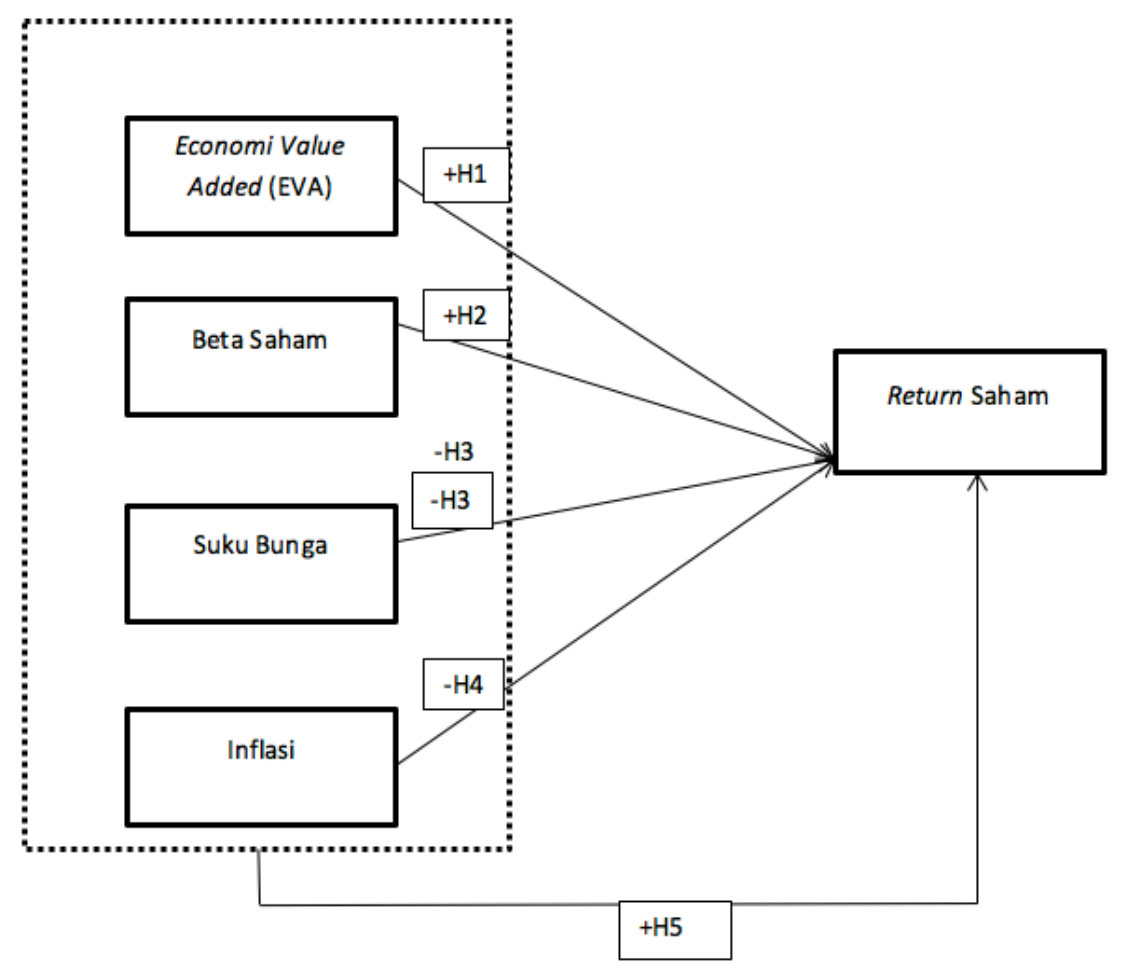

sistematis, Tingkat Suku Bunga dan Inflasi berpengaruh secara simultan terhadap return saham.

\section{METODE PENELITIAN}

\section{Sifat Penelitian}

Penelitian ini bersifat deskriptif kuantitatif, yaitu menjelaskan hubungan satu sama lain secara simultan dan parsial antara variabel independen terhadap variabel dependen.

\section{Variabel Independen Economic value added (EVA).}

Menurut Hansen dan Mowen (2009), EVA adalah laba bersih (laba operasi dikurangi pajak) dikurangi total biaya modal tahunan. EVA pada dasarnya adalah laba residu dengan biaya modal sama dengan biaya modal aktual dari perusahaan sebagai ganti dari suatu tingkat pengembalian minimum yang diinginkan perusahaan karena alasan lainnya. Jadi,. Hitungan Economic Value Added (EVA) sebagai berikut :

$$
\text { EVA }=\text { NOPAT }- \text { Capital Charges }
$$

Atau

$E V A=$ NOPAT $-($ WACC $X$ Invested Capital $)$

\section{Risiko sistematis (Beta saham)}

Jika perubahan pasar dinyatakan sebagai tingkat keuntungan indeks pasar, maka tingkat keuntungan suatu saham dalam konsep model indeks tunggal dapat dinyatakan sebagai berikut :

Dimana:

$$
R_{i}=a_{i}+\beta_{i} R_{m}
$$

$\mathrm{R}_{\mathrm{i}}$ adalah Tingkat keuntungan saham i.

$a_{i}$ adalah bagian dari tingkat keuntungan saham i yang tidak dipengaruhi oleh perubahan pasar. Variabel ini merupakan variabel yang acak.

$\beta_{i}$ adalah Beta, merupakan parameter yang mengukur perubahan yang diharapkan pada $R_{i}$ jika terjadi perubahan pada $R_{m}$.

$R_{m}$ adalah tingkat keuntungan indeks pasar. variabel ini merupakan variabel yang acak.

Beta sebagai pengukur risiko yang berasal dari hubungan antara tingkat 
keuntungan suatu saham dengan pasar.

\section{Indikator makro ekonomi : Suku Bunga}

Tingkat suku bunga merupakan suku bunga kebijakan yang mencerminkan sikap kebijakan moneter yang ditetapkan oleh Bank Indonesia dan diumumkan kepada publik. Tingkat suku bunga yang digunakan dalam penelitian ini adalah tingkat suku bunga pada bulan di olah menjadi ratarata tahun periode tahun 2011-2015. Untuk mendapatkan data suku bunga dapat dilihat melalui website Bank Indonesia di www. bi.go.id di menu moneter lalu pilih BI Rate.

\section{Inflasi}

Inflasi merupakan salah satu indikator untuk melihat stabilitas ekonomi suatu wilayah atau daerah yang menunjukkan perkembangan harga barang dan jasa secara umum yang dihitung indeks harga konsumen. Data inflasi yang digunakan dalam penelitian ini adalah data laporan inflasi bulanan diolah menjadi rata-rata tahun. Data inflasi bisa didapatkan melalui website Bank Indonesia di www.bi.go.id di menu moneter lalu pilih menu inflasi.

\section{Variabel Dependen Return saham}

Return saham merupakan hasil baik keuntungan maupun kerugian yang diperoleh dari investasi saham. Return saham dibedakan menjadi dua yaitu return realisasi (realized return) dan return ekspektasi (expected return). Return yang di terima oleh investor di pasar modal dibedakan menjadi dua jenis yaitu current income (pendapatan lancar) dan capital gain/ capital loss (keuntungan selisih harga). Hitungan return saham adalah sebagai berikut:

Return Saham Realisasi $=$

Harga Saham Sesudah - Harga Saham Sebelum Harga Saham sesudah

\section{Populasi, Sampel, dan Teknik Pengambilan Sampel}

Populasi dalam penelitian ini adalah perusahaan Manufaktur yang terdaftar di Bursa Efek Indonesia pada periode 2011-2015. Dari direktori tersebut, jumlah perusahaan subsektor otomotif selama periode penelitian sejumlah 17 perusahaan. Dalam penelitian ini menggunakan sampel perusahaan manufaktur subsektor Otomotif yang terdiri dari 7 perusahaan yang terdaftar di Bursa Efek Indonesia.teknik pengambilan sampel ini menggunakan Purposive sampling.

\section{Teknik Analisis Data}

Data hasil penelitian dianalisis dengan alat statistik yang terdiri dari analisis deskriptif, uji asumsi klasik (uji normalitas, uji heterokedastisitas, uji autokorelasi dan uji multikolonieritas), uji hipotesis, uji stepwise dan analisis regresi berganda yang diolah dengan menggunakan SPSS 17.

\section{HASIL PENELITIAN DAN PEMBAHASAN Deskripsi Data Variabel Penelitian}

Hasil analisis statistik deskriptif terhadap variabel-variabel pada penelitian ini secara

Tabel 1

Analisis Statistik Deskriptif

\begin{tabular}{llllll}
\hline Variabel & $\mathrm{N}$ & Min & Max & Mean & $\begin{array}{l}\text { S t a n d a r t } \\
\text { Deviasi }\end{array}$ \\
\hline EVA $\left(\mathrm{X}_{1}\right)$ & 35 & -110087 & 592749 & 158124,9 & 164456,7 \\
Beta Saham $\left(\mathrm{X}_{2}\right)$ & 35 & $-0,54575$ & 0,39283 & 0,337726 & 0,13428287 \\
Suku Bunga $\left(\mathrm{X}_{3}\right)$ & 35 & 5,77 & 7,54 & 6,8860 & 0,67097 \\
Inflasi $\left(\mathrm{X}_{4}\right)$ & 35 & 4,28 & 6,97 & 5,7660 & 0,93373 \\
Return Saham $(\mathrm{Y})$ & 35 & $-0,49846$ & 0,85662 & 0,1000211 & 0,2936333 \\
\hline
\end{tabular}

Faktor-Faktor yang Mempengaruhi...... (S.Hermuningsih, Anisya D R \& Mujino) 
Tabel 2

Disitribusi Normal

\begin{tabular}{lccc}
\hline Distribusi Data Variabel & $\begin{array}{c}\text { Kolmogorov- } \\
\text { Smirnov } \mathbf{Z}\end{array}$ & $\boldsymbol{p}$-Value & Kesimpulan \\
\hline EVA $\left(\mathrm{X}_{1}\right)$ & 1,024 & 0,245 & Normal \\
Beta Saham $\left(\mathrm{X}_{2}\right)$ & 1,221 & 0,101 & Normal \\
Suku Bunga $\left(\mathrm{X}_{3}\right)$ & 1,347 & 0,053 & Normal \\
Inflasi $\left(\mathrm{X}_{4}\right)$ & 0,936 & 0,345 & Normal \\
Return Saham $(\mathrm{Y})$ & 0,597 & 0,868 & Normal \\
Standardized Residual & 1,295 & 0,070 & Normal \\
\hline
\end{tabular}

ringkas disajikan pada tabel berikut ini.

Pada tabel di atas dapat dilihat bahwa variabel return saham memiliki nilai terendah $-0,49846$ dan nilai tertinggi 0,85662 dengan nilai rata-ratanya 0,1000211 dan deviasi standar 0,2936333. Analisis deskriptif pada variabel Economic Value Added (EVA) didapatkan nilai terendah $-0,110087$ dan nilai tertinggi 592749 dengan nilai rata-rata 158124,9 dan deviasi standar 164456,7. Analisis deskriptif pada variabel beta saham didapatkan nilai terendah $-0,54575$ dan nilai tertinggi 0,39283 dengan nilai rata-rata 0,337726 dan deviasi standar 0,13428287.

Hasil analisis deskriptif pada variabel suku bunga didapatkan nilai terendah 5,77 dan nilai tertinggi 7,54 dengan nilai rata-rata 6,886 dan deviasi standar 0,67097. Analisis deskriptif pada variabel inflasi didapatkan nilai terendah 4,28 dan nilai tertinggi 6,97 dengan nilai rata-rata 5,766 dan deviasi standar 0,93373 .

\section{Uji Asumsi Klasik}

Uji asumsi klasik meliputi uji normalitas, heterokedastisitas, autokorelasi dan multikolonieritas.

Uji normalitas bertujuan untuk menguji apakah model regresi, Variabel terikat dan variabel bebas keduanya memilki distribusi normal atau tidak. Model regresi yang baik adalah memiliki distribusi data normal atau mendekati normal. Uji normalitas menggunakan uji kolmogrov-Smirnov, dimana suatu data dikatakan normal apabila nilai .sig > 0,05 (Ghozali, 2001).

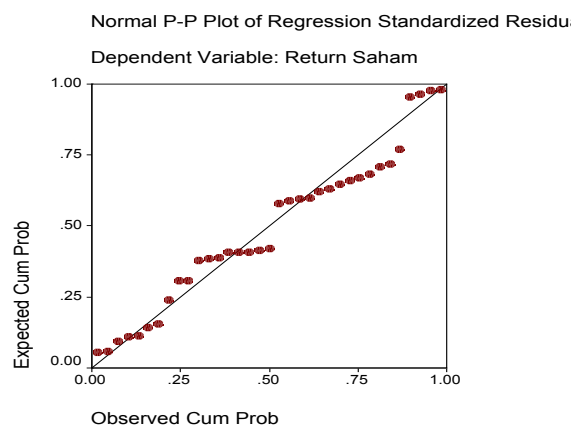

Gambar 1 Uji Normalitas

\section{Uji Heterokedastisitas}

Uji Heterokesdatisitas bertujuan untuk mengetahui apakah dalam sebuah model regresi terjadi ketidaksamaan varians dari residu suatu pengamatan ke pengamatan lain. Uji heteroskedastisitas pada penelitian ini menggunakan pengujian secara grafis, yaitu grafik scatterplot. Dengan bantuan komputer, dapat disajikan scatterplot sebagai berikut:

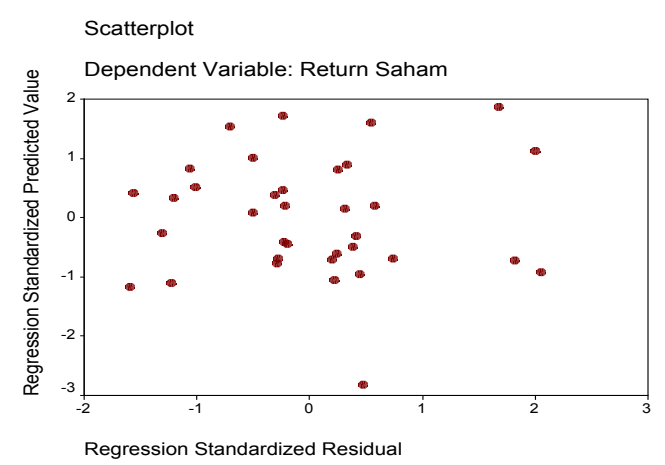

Gambar 2 Uji Heteroskedastisitas 
Tabel 3

Uji Heterokedastisitas

\begin{tabular}{lllll}
\hline Variabel Bebas & $\mathrm{B}$ & $\mathrm{T}$ & $\begin{array}{l}\text { Sig. } \\
(\mathrm{p})\end{array}$ & Keterangan \\
\hline EVA $\left(\mathrm{X}_{1}\right)$ & $-9.1 \mathrm{E}-07$ & $-1,424$ & 0,165 & Tidak Terjadi Hetero \\
Beta Saham $\left(\mathrm{X}_{2}\right)$ & 0,250 & 0,324 & 0,748 & Tidak Terjadi Hetero \\
Suku Bunga $\left(\mathrm{X}_{3}\right)$ & $-0,337$ & $-1,386$ & 0,176 & Tidak Terjadi Hetero \\
Inflasi $\left(\mathrm{X}_{4}\right)$ & 0,063 & 0,361 & 0,720 & Tidak Terjadi Hetero \\
\hline
\end{tabular}

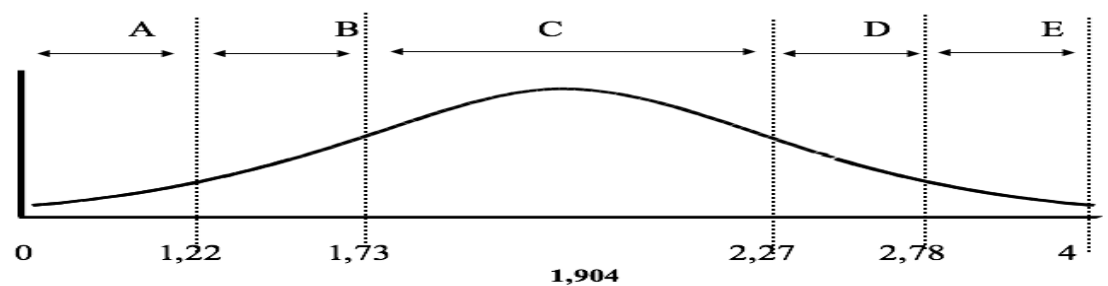

Gambar 3. Hasil Uji Autokorelasi (Durbin-Watson Test)

Grafik di atas menunjukkan bahwa grafik yang dibentuk oleh scatterplot of regression standardized predicted value dengan standardized residual berada di sekitar 0 .

Selain dengan grafik tersebut di atas, pada penelitian ini uji heteroskedastisitas diuji dengan uji Glejser. Uji heteroskedastisitas dengan uji Glejser bertujuan untuk menguji apakah dalam model regresi tersebut terjadi ketidaksamaan variance dari residual satu pengamatan ke pengamatan yang lain. Model regresi yang baik maka tidak terjadi heteroskedastisitas.

Bahwa semua variabel memiliki nilai $p>0,05$, yang berarti tidak terjadi masalah heteroskedastistitas.

\section{Uji Autokorelasi}

Uji autokorelasi bertujuan untuk menguji apakah dalam suatu model regresi linear ada korelasi antara kesalahan pengganggu pada periode $t$ dengan kesalahan periode t-1 (sebelumnya). Dari tabel Durbin Watson, dengan menggunakan taraf kepercayaan 95\% (5\% significant points of $d_{L}$ and $\left.d_{u}\right)$ pada $\mathrm{K}=4$ dan $\mathrm{n}=35$, diperoleh nilai $\mathrm{d}_{\mathrm{L}}=$
1,22 dan $d_{u}=1,73$. Dari keterangan tersebut dapat diimplementasikan dalam gambar sebagaimana gambar 3 .

Keterangan:

Daerah A adalah daerah penolakan Ho (bukti terdapat autokorelasi positif).

Daerah E adalah daerah penolakan Ho (bukti terdapat autokorelasi negatif). Daerah C adalah daerah penerimaan Ho (tidak terdapat autokorelasi).

Daerah B dan D adalah daerah keragu-raguan.

Dari hasil regresi, diperoleh DW sebesar 1,904 yang terletak pada daerah $\mathrm{C}$, yaitu daerah tidak terdapat autokorelasi. Dengan demikian syarat tidak terjadi autokorelasi telah terpenuhi.

\section{Uji Multikolonieritas}

Pengujian multikolinearitas bertujuan untuk mengetahui ada tidaknya hubungan tumpang tindih antar variabel bebas. Uji ini diperlukan, karena penelitian ini menggunakan analisis regresi moderasian. 
Tabel 4

Hasil Uji Multikolonieritas

\begin{tabular}{cccl}
\hline \multirow{2}{*}{ Variabel Bebas } & \multicolumn{2}{c}{ Collinearity Statistics } & \\
\cline { 2 - 3 } & Tolerance & VIF & \multirow{2}{*}{ Kesimpulan } \\
\hline EVA $\left(\mathrm{X}_{1}\right)$ & 0,905 & 1,106 & Tidak Terjadi Multikolinearitas \\
\hline Beta Saham $\left(\mathrm{X}_{2}\right)$ & 0,931 & 1,074 & Tidak Terjadi Multikolinearitas \\
\hline Suku Bunga $\left(\mathrm{X}_{3}\right)$ & 0,375 & 2,667 & Tidak Terjadi Multikolinearitas \\
\hline Inflasi $\left(\mathrm{X}_{4}\right)$ & 0,378 & 2,645 & Tidak Terjadi Multikolinearitas \\
\hline
\end{tabular}

Tabel 5

Regresi Liner Berganda

\begin{tabular}{|c|c|c|c|c|c|}
\hline \multirow[t]{2}{*}{ Variabel Bebas } & \multicolumn{2}{|c|}{$\begin{array}{l}\text { Unstandardized } \\
\text { Coefficients }\end{array}$} & \multirow{2}{*}{$\begin{array}{l}\text { Standardized } \\
\text { Coefficients }\end{array}$} & \multirow[t]{2}{*}{$\mathrm{t}$} & \multirow{2}{*}{$\begin{array}{l}\text { Sig. } \\
\text { (p) }\end{array}$} \\
\hline & B & $\begin{array}{l}\text { Std. } \\
\text { Error }\end{array}$ & & & \\
\hline (Constant) & 1,05035 & 0,439 & -- & -- & -- \\
\hline $\operatorname{EVA}\left(\mathrm{X}_{1}\right)$ & 5,3319E-07 & 0,000 & 0,299 & 2,151 & 0,040 \\
\hline Beta Saham $\left(\mathrm{X}_{2}\right)$ & 0,70308 & 0,299 & 0,322 & 2,350 & 0,026 \\
\hline Suku Bunga $\left(\mathrm{X}_{3}\right)$ & $-0,10348$ & 0,094 & $-0,236$ & $-1,097$ & 0,282 \\
\hline Inflasi $\left(\mathrm{X}_{4}\right)$ & $-0,5998$ & 0,068 & $-0,191$ & $-0,888$ & 0,381 \\
\hline \multicolumn{3}{|c|}{$\mathrm{R}$} & \multicolumn{3}{|c|}{$=0,691$} \\
\hline \multicolumn{3}{|c|}{ R Square $\left(R^{2}\right.}$, & \multicolumn{3}{|c|}{$=0,477$} \\
\hline \multicolumn{3}{|c|}{ Std Error of the Estimate (e) } & \multicolumn{3}{|c|}{$=0,22606846$} \\
\hline \multicolumn{3}{|c|}{$\mathrm{F}_{\text {hitung }}$} & \multicolumn{3}{|c|}{$=6,840$} \\
\hline \multicolumn{3}{|c|}{ Sig. (p) } & \multicolumn{3}{|c|}{$=0,000$} \\
\hline
\end{tabular}

Uji multikolonieritas dilakukan dengan melihat nilai Variance Inflation Factor (VIF), apabila nilai VIF $<10$ dan nilai tolerance $>$ 0,1 maka tidak terjadi gejala multikolonieritas (Ghozali, 20015). Tabel 4 menunjukan hasil uji multikolonieritas.

\section{Hasil dan Pembahasan Uji Hipotesis}

Hasil analisis uji t menyatakan $\mathrm{H} 1$ dan $\mathrm{H} 2$ diterima karena niai sig $<0,05$, sedangkan $\mathrm{H} 3$ dan $\mathrm{H} 4$ ditolak karena pada tabel nilai sig $>0,05$. Dan hasil analisis uji $F$ menyatakan $\mathrm{H} 1, \mathrm{H} 2, \mathrm{H} 3$ dan $\mathrm{H} 4$ diterima karena niai sig $0,000<0,05$. Hasil uji ini dapat dilihat pada tabel regresi liner berganda.

\section{Pembahasan}

Pengaruh Secara Simultan Economic Value Added, Risiko Sistematis, Tingkat Suku Bunga dan Inflasi Terhadap Return Saham.

Penelitian ini membuktikan bahwa economic value added, risiko sistematis, tingkat suku bunga dan inflasi berpengaruh signifikan secara simultan terhadap return saham pada perusahaan manufaktur yang dikategorikan pada perusahaan subsektor otomotif. Hasil ini dibuktikan dengan nilai koefisien korelasi ganda $(R)$ sebesar 0,691 ; koefisien determinan $\left(R^{2}\right) \quad 0,407 ; \quad F_{\text {Regresi }}$ 6,840; dan signifikansi dari $F_{\text {Regresi }}$ sebesar 0,000 . Terbukti $p$-value kurang dari taraf signifikansi yang ditentukan, yaitu $5 \%$ 
$(p<0,05)$, maka disimpulkan $F_{\text {Regresi }}$ tersebut signifikan.

Pengaruh Secara Parsial Economic Value Added, Risiko Sistematis, Tingkat Suku Bunga dan Inflasi Terhadap Return Saham

\section{Pengaruh Economic Value Added Terhadap Return Saham}

Economic value added berpengaruh positif dan signifikan secara parsial terhadap return saham pada perusahaan manufaktur yang dikategorikan pada perusahaan subsektor otomotif. Hal ini dibuktikan dengan $t_{\text {hitung }}=2,151$ dengan $p$-value $=0,040$ $(p<0,05)$. Hasil penelitian ini sejalan dengan hasil penelitian yang dilakukan Ansori (2015). Hal ini menunjukakan bahwa semakin tinggi economic value added, semakin tinggi pula return saham. Economic Value Added sangat relevan, dikarenakan Economic Value Added dapat mengukur prestasi manajemen berdasarkan nilai tambah yang diciptakan selama periode tertentu pada perusahaan manufaktur yang dikategorikan pada perusahaan subsektor otomotif.

\section{Pengaruh Risiko Sistematis (Beta Saham) Terhadap Return Saham}

Risiko sistematis atau beta saham berpengaruh positif dan signifikan secara parsial terhadap return saham pada perusahaan manufaktur yang dikategorikan pada perusahaan subsektor otomotif. Hasil ini dibuktikan dengan $t_{\text {hitung }}=2,350$ dengan $p$-value $=0,026 \quad(p<0,05) . \quad$ Hasil penelitian ini sejalan dengan hasil penelitian yang dilakukan Santoso (2011). Hal ini menunjukakan bahwa Pengaruh positif dan signifikan ini berarti bahwa semakin tinggi Risiko sistematis atau beta saham, semakin tinggi pula return saham dan sebaliknya semakin rendah Risiko sistematis atau beta saham, semakin rendah pula return saham pada perusahaan manufaktur yang dikategorikan pada perusahaan subsektor otomotif.

\section{Pengaruh Suku Bunga Terhadap Return Saham}

Suku bunga tidak menunjukkan adanya yang signifikan secara parsial terhadap return saham pada perusahaan manufaktur yang dikategorikan pada perusahaan subsektor otomotif. Hasil ini dibuktikan dengan $\mathrm{t}_{\text {hitung }}=$ $-1,097$ dengan $p$-value $=0,0282(p>0,05)$. Hasil penelitian ini sejalan dengan hasil penelitian yang dilakukan Nini Safitri Aziz (2012). Hasil penelitian ini mengindikasikan bahwa perubahan suku bunga akan mempengaruhi harga saham secara terbalik. Artinya jika suku bunga meningkat, maka harga saham akan turun dan sebaliknya (Tandelilin: 2001:48). Harga saham yang turun ini akan menyebabkan return saham yang turun pula. Hal ini disebabkan karena dalam menghadapi kenaikan suku bunga. para pemegang saham akan menahan sahamnya sampai tingkat suku bunga kembali pada tingkat yang dianggap normal. Sebaliknya, jika tingkat suku bunga jangka panjang meningkat maka pemegang saham cenderung menjual sahamnya karena harga jualnya tinggi. Kenaikan suku bunga akan sangat berpengaruh bagi pelaku pasar modal. Pergerakan suku bunga SBI yang fluktuatif dan cenderung meningkat akan mempengaruhi pergerakan sektor riil yang dicerminkan oleh pergerakan return saham. Akibat meningkatnya suku bunga, para pemilik modal akan lebih suka menanamkan uangnya di bank dari pada berinvestasi dalam bentuk saham.

\section{Pengaruh Inflasi Terhadap Return \\ Saham}

Inflasi berpengaruh negatif dan tidak signifikan secara parsial terhadap return saham pada perusahaan manufaktur yang dikategorikan pada perusahaan subsektor otomotif. Hasil analisis pada analisis regresi ganda, didapatkan $t_{\text {hitung }}=-0,888$ dengan $p$-value $=0,381 \quad(p>0,05)$. Hasil penelitian ini sejalan dengan hasil penelitian yang dilakukan Nini Safitri Aziz (2012). Hal ini menunjukankan bahwa Pengaruh negatif 
dan tidak signifikan terhadap return saham karena ekonomi di indonesia saat ini sudah mulai kuat dan meningkat secara tidak langsung akan berpengaruh pada pendapatan masyarakat, sehingga berpengaruh pada peningkatan inflasi.

Pengaruh Secara Dominan (Stepwise)

Berdasarkan hasil uji Stepwise menunjukakan bahwa variabel Economic Value Added (EVA) didapatkan koefisien beta $\left(b_{1}\right)-4,245 \times 10^{-7}$ dengan $t_{\text {hitung }}=-2,700$ dengan $p$-value $=0,01011(p<0,05)$. Hal ini menunjukkan bahwa Economic Value Added (EVA) merupakan variabel yang paling dominan berpengaruh pada Return Saham.

\section{SIMPULAN}

Berdasarkan hasil analisis data dan pembahasan, dapat diambil beberapa kesimpulan, antara lain:

Economic value added, dan risiko sistematis berpengaruh signifikan secara parsial terhadap return saham pada perusahaan manufaktur yang dikategorikan pada perusahaan subsektor otomotif, sedangkan suku bunga dan inflasi tidak menunjukkan pengaruh yang signifikan

a. Economic Value Added (EVA) berpengaruh positif yang signifikan terhadap return saham pada perusahaan manufaktur yang dikategorikan pada perusahaan subsektor otomotif.

b. Risiko sistematis (beta saham) berpengaruh positif yang signifikan terhadap return saham pada perusahaan manufaktur yang dikategorikan pada perusahaan subsektor otomotif.

d. Tingkat suku bunga tidak berpengaruh secara signifikan terhadap return saham pada perusahaan manufaktur yang dikategorikan pada perusahaan subsektor otomotif.

e. Inflasi tidak berpengaruh secara signifikan terhadap return saham pada perusahaan manufaktur yang dikategorikan pada perusahaan subsektor otomotif.

Economic value added, risiko sistematis (beta saham), suku bunga dan inflasi berpengaruh signifikan secara simultan terhadap return saham pada perusahaan manufaktur yang dikategorikan pada perusahaan subsektor otomotif.

1. Variabel Economic Value Added (EVA) merupakan variabel yang paling dominan berpengaruh terhadap return saham pada perusahaan manufaktur yang dikategorikan pada perusahaan subsektor otomotif.

\section{DAFTAR PUSTAKA}

Akhmad Arif Imam Santoso (2011). Pengaruh Nilai Tukar, Inflasi, Debt To Equity Ratio, Return On Asset, Beta Saham, Return Saham (Studi Empiris Pada Perusahaan LQ - 45 Di Bursa Efek Indonesia. Jakarta : Universitas Islam Negeri Syarif Hidayatullah.

Ansori. (2015). "Pengaruh Economic Value Added dan Market Value Added terhadap Return Saham Pada Perusahaan Manufaktur yang Terdaftar Di Bursa Efek Indonesia". Skripsi. Yogyakarta: Universitas Negeri Yogyakarta.

Darmadji, Tjiptono \& Fakhruddin, Hendy M. (2006). Pasar Modal di Indonesia. Jakarta: Salemba Empat. hal 5

Ghozali, Imam. 2001. Aplikasi Analisis Multivarite dengan Program IBIN SPSS 19. Semarang. Badan Penerbit Universitas Diponegoro. hal 99-105

Hansen, Don, R., \& Mowen, Maryanne M. (2009). Akuntansi Manajerial. Jakarta: Salemba Empat. hal 585

Husnan, Suad \& Pudjiastuti, Enny. (2006). Dasar-dasar Manajemen Keuangan. Yogyakarta : UPP STIM YKPN. hal 29 
Hermuningsih, Sri. 2012. Pengantar Pasar Modal Indonesia. Yogyakarta. UPP STIM YKPN. hal 2

Iswardono. 1999.Uang dan Bank, Edisi Empat.Yogyakarta. BPFE. hal 246

Jogiyanto. 2003. Teori Portofolio dan Analisis Investasi. Edisi Ketiga. Yogyakarta. hal 344-346

Safitri, Nini. (2012). Pengaruh Return On Asset (Roa), Debt To Equity Ratio (Der), Tingkat Suku Bunga Dan Tingkat Inflasi Terhadap Return Saham Sektor Perbankan Di Bursa Efek Indonesia (Periode 2003-2010). Jurnal Ekonomi : Universitas Hasanuddin Makassar.

Sunariyah. 2003. Pengantar Pengetahuan Pasar Modal, Edisi ketiga. Yogyakarta. UPP AMP YKPN. hal 45

Tandelilin, Eduardus. 2001. Analisis Investasi dan Manajemen Portofolio. Yogyakarta. BPFE. hal 48

www.bi.go.id 